\title{
Effect of Wheatgrass (Triticum aestivum Linn) Extracts as Source of Antioxidants on some biochemical parameters and Markers of Aging \\ El-Sayeda G. E. El-Sahar
}

\author{
Home Economic Department, Faculty of Specific Education, Ain Shams \\ University, Cairo, Egypt
}

Email: dr_sayeda2015@yahoo.com

\begin{abstract}
Aging is defined of the process of getting older, or an artificial process to make someone or something look older and loss of function. There has been a global trend toward using of natural phytochemicals present in natural sources as antioxidants and functional foods. Wheatgrass has been proved to contain essential amino acids, active enzymes, flavonoids, chlorophyll, minerals, proteins and vitamins This study was aimed to see the effect of ethanolic and water extracts of wheat grass as natural sources of antioxidants on markers of aging in rats. 36 Sprague-Dawley female rats were obtained. six rats weighing 112 to $125 \mathrm{~g}$ considered as control young and therefore the rest of rats weighing 256 to 267 $\mathrm{g}$ considered as aged rats their age ranges between 18 month and to 24 month. The rats were divided into 5 groups, the primary and second groups consumed basal diet and thought of as control young and control aged rats, respectively, while the opposite four groups administered ethanolic and water extracts of Wheatgrass powder at doses of 10 and $20 \mathrm{mg}$ for every rat once daily. Blood samples were taken from rats and examined for markers of aging as, the activity of SOD and lipid peroxidation (MDA), total cholesterol, HDL, LDL, VLDL, triglycerides levels and liver functions. Aging resulted during a significant deterioration altogether tested markers of aging including, SOD and MDA, total protein, globulin, albumin HDL-cholesterol. Also, a big increase in, ALT, AST triglycerides, total cholesterol, LDL and VLDL levels was observed during aging. Administering aged rats with Wheatgrass ethanolic and water extracts caused a big improvement within the above markers and returned the abnormal markers back to the traditional levels Approximately as found on top of things young rats especially at $20 \mathrm{mg}$ from wheatgrass. So, it might be recommended that wheatgrass ethanolic extracts (70) might be wont to improve the abnormal changes in health state of aging human and return them to just about the
\end{abstract}


traditional state found in younger human by employing a natural source of antioxidants like Wheatgrass.

Key words: Aging; Antioxidants; Ethanolic extract; Water extract; Wheatgrass.

\section{Introduction:}

The world's population is aging rapidly, with the over-65 age bracket outnumbering the below-15 age bracket during a fast increasing number of nations (Von Bohlen et al., 2006). and oxidative damage by reactive oxygen species (ROS) is usually related to aging (Barja, 2004). during this context, the term "inflammaging" has become widely wont to describe the characteristic inflammatory process of aging. Inflammaging is characterized by a subclinical, low-grade, chronic systemic pro-inflammatory state (Xia et al., 2016) During this process, the balance of cytokines within the body undergoes changes, probably because of loss of homeostasis, which contributes to a greater predisposition to illness and worsening of chronic diseases like hypertension and diabetes. Thus, inflammaging seems to be related to increased morbidity and mortality within the elderly (Flynn et al., 2019) and (Schnabel et al., 2013).

Kamboj et al. (2011) mentioned that Wheatgrass is extremely nutritious and it's widely used as a food supplement because it prevents physical body from various health issues also as improves immunity.

Sofi et al. (2016) stated that Wheatgrass supplies the body with helpful measurements of vitamins, minerals, cancer prevention agents, chemicals, and phytonutrients, wheatgrass is likewise a capable detoxifier, particularly of the liver and blood. It kills poisons and ecological contaminations within the body. this is often on account of Wheatgrass contains useful compounds that shield 
us from cancer-causing agents, including SOD (SOD), that decreases the impacts of radiation and overview poisons within the body. It scrubs the body from head to toe of any overwhelming metals, poisons and different poisons which may be put away within the body's tissues and organs.

Wheatgrass is rich in chlorophyll which is a crucial phytopigment that has an anti-bacterial effect; meanwhile, the chlorophyll of wheatgrass is related to many health benefits and rebuilds the bloodstream. Studies revealed that animals that intake chlorophyll within the diet are freed from any toxic reaction (DeVogel et al. 2005). within the same time, chlorophyll may be a potent antioxidant with an impact on cancer prevention. Additionally, selenium and laetrile exist in wheatgrass have anti-cancer activity. Selenium is incorporated as a bioactive natural element that enhances the system and may reduce the danger factors of cancer. Wheatgrass comprises of in any case 13 vitamins that include B12 and abscisic acid additionally to cytochrome oxidase, and mucopolysaccharide (Ferruzzia and Blakesleeb 2007; Wheat and Currie 2008).

The aim of this study is to see the effect of ethanolic and water extracts of Wheatgrass (Triticum aestivum Linn) powder on markers of aging in rats as natural sources of antioxidants.

\section{MATERIALS AND METHODS:}

\section{Materials:}

Wheatgrass (Triticum aestivum Linn) were obtained from medicinal plants and agricultural seeds breeding section, Field Crops Department, Agricultural Research Centre, Giza, Egypt. Wheatgrass samples were used for all processing trials. Tops were stop at $10 \mathrm{~cm}$ above soil level, and roots comprised the remainder of the plant. In First, the fresh wheatgrass cleaned, soon after cutting it on a pounding basin, Leaves of Wheatgrass (Triticum 
aestivum Linn) were left on air at temperature for 2 weeks to be alright dried. then, they were crushed up and ground to urge homogeneous fine powder by a grinder then kept during a dark place at temperature till their use in extraction (Farhan, et al., 2012). Wheatgrass (Triticum aestivum Linn) powder were extracted in ethanol (E. Merck, Germany) by Soxhelt extraction method as described by (Vogel et al., (1978). The Extracts were prepared by shaking the leaves with ethanol ( $70 \%$ ) or water for twenty-fourhrs. At temperature to get ethanolic and water extracts. After complete drying of the extracts by evaporation the residues were stored at $-30^{\circ} \mathrm{C}$ within the dark and used as powder as described by Lalone et al., (2007).

\section{Animals and Experimental Diets:}

A total of 36 Sprague-Dawley male rats were obtained from Food Technology Research Institute, Agricultural Research Centre, Giza, Egypt. 6 rats weighing from 102 to $112 \mathrm{~g}$ considered as control young and therefore the remainder of rats ( 30 rats) weighing from 256 to $267 \mathrm{~g}$ considered as aged rats were housed in plastic cages and ate up basal diet and water for one week as an adaptation period. The basal diet composed of casein (12\%), cellulose $(5 \%)$, vitamins mixture (1\%), salts mixture (4\%), vegetable oil (5\%) and corn starch (73\%). The basal diet formulation was performed consistent with A.O.A.C (2006). The rats were divided into 6 groups, each group contained six rats. the primary group ate up basal diet and thought of as an impact young group. The second group ate up basal diet and thought of as an impact aged rats, while the opposite four groups administered the ethanolic and water extracts of Wheatgrass (Triticum aestivum Linn) powder at doses of $10 \mathrm{mg}$ and $20 \mathrm{mg}$ for every rat once daily employing a stomach tube before meal for 35 days. weight was taken twice weekly during the experimental period. At the top of the experiment blood samples of rats were taken by using fine capillary 
glass tubes from orbital plexus venous. Blood samples could clot for one min. at $37^{\circ} \mathrm{C}$, centrifuged at $1500 \mathrm{xg}$ for $10 \mathrm{~min}$. and therefore the separated serum was kept frozen at $-20^{\circ} \mathrm{C}$ until analysis.

\section{Biochemical Analysis:}

Serum total cholesterol, low-density lipoprotein cholesterol, highdensity lipoprotein cholesterol and triglycerides were determined consistent with the methods of Roeschlau et al., (1974); Hatch and Lees (1968), Assmann (1979) and Uwajima et al., (1984), respectively. Very LDL cholesterol (VLDL-C) was administered consistent with Lee and Nieman (1996) as follows VLDL-C $=\mathrm{TC}-(\mathrm{HDL}-\mathrm{c})-(\mathrm{LDL}-\mathrm{c})$.

Aspartate aminotransferase (AST) and alanine aminotransferase (ALT) activities were colorimetrically determined consistent with the tactic of Bergmeyer and Harder (1986). Serum total protein content was estimated by the tactic of Lowry et al. (1951) using bovine albumin as standard. Albumin decided by an enzyme-linked immunosorbent assay as described by Borcea et al. (1999). Globulin was calculated by subtracting albumin from serum total protein content. The activity of Superoxide dismutase of rats serum were estimated consistent with Marklund and Marklund (1974) and Habig et al. (1974). the tactic of Begona et al., (1994) was used for the determination of lipid peroxides. malondialdehyde (MDA).

\section{Statistical Analysis:}

The obtained data were exposed to analysis of variance. Duncan's multiple range tests at $(\mathrm{P} \leq 0.05)$ level want to compare between means. The analysis was administered using the professional ANOVA procedure of Statistical Analysis System (SAS, 1996).

\section{RESULTS AND DISCUSSION:}

Effect of Wheatgrass powder Extracts on weight in Aged Rats: 
Data presented in Table (1) show the effect of Wheatgrass powder extracts on weight in aged rats from zero time to the top of the experiment (35 days). weight of control young rats wasn't significantly different during the experimental period, but it had been significantly different compared with weight of control aged rats at the start and therefore the end of the experimental period. There was insignificant difference in weight of control aged rats at zero time and therefore the decrease in weight at the top of the experiment was statistically significant. Administering Wheatgrass ethanolic and water extracts orally to rats caused a big decrease in weight at the top of the experiment. The reduction in weight was $12.7 \%, 15.3 \%$ and $13.8 \%, 20.4 \%$ for water extract and ethanolic extract of wheatgrass at $10 \mathrm{mg}$ and $20 \mathrm{mg}$, respectively, compared with control aged rats at the top of the experiment.

The decrease in weight was bit by bit however not suddenly throughout the time experiment intervals. wheat-grass ethanolic extract $(20 \mathrm{mg}$ ) was more practical in weight loss compared with wheatgrass water extract. These results united with discovered by (Desai and Tusharbindu, 2005) World Health Organization registered that wheatgrass safe and intensely potent aid to weight loss since it suppresses the appetency and stimulates circulation and metabolism, it's additionally extremely effective to scale back weight or accomplish weight loss

These results were in line with the results reportable by Ghoniem et al., (2018) World Health Organization incontestable wheat grass juice and its blends ends up in decrease initial weight compared management cluster and increase final weight and food intake compared management cluster. 
consumption of pigment containing elements of inexperienced plants, in overweight patients ends up in vital weight reduction and reduction in blood sterol beside a reduced urge for appetizing food.

The mechanism suggests associate increased meal-related Glucagon-like peptide-1 unharness that sustained throughout the intervention amount. Green-plant membranes could therefore be a brand new agent for management of appetency and weight (Montelius et al., 2014).

This result could also be thanks to the wheat grass extracts possess antiinflammatory drug and inhibitor activities (Shah, 2007 and Ben-Arye et al., 2002).

\section{Effect of wheat-grass powder Extracts on inhibitor accelerator (SOD) and supermolecule peroxidation (MDA) in Aged Rats:}

Table (2) shows the result of wheat-grass extracts on inhibitor enzymes, SOD activities as markers of aerophilous stress in aged rats. blood serum SOD levels were considerably reduced in aged rats compared with management young rats as a results of aerophilous stress related to aging. All groups of aged rats take basal diet and administered wheat-grass ethanolic and water extracts resulted in a rise in serum SOD levels $(27.47 \pm 1.94,34.46 \pm 1.91,31.92 \pm 1.41$ and $40.30 \pm$ 1.00) n. mol/mg/ protein respectively, compared with control aged rats at the end of the experiment. The rise in serum SOD levels was statistically vital $(\mathrm{p}<0.05)$. wheat-grass ethanolic extract $\quad\left(\begin{array}{lll}20 & \mathrm{mg}\end{array}\right)$ caused vital increase compared with wheat-grass water extract and management young rats. From Table (2) it can be discovered that MDA levels were increase in aged rats $(14.55 \pm 1.15)$ compared with young rats $(0.52 \pm 0.04)$ as a results of aging that increase aerophilous stress. Administering wheat-grass ethanolic and water extracts orally to aged rats 
caused vital decrease in MDA levels of water and ethanolic extracts at $10 \mathrm{mg}$ $(9.83 \pm 0.58,7.84 \pm 0.46)$, respectively compared with control aged rats at the end of the experiment and also the best results found at $20 \mathrm{mg}$ of wheatgrass ethanolic extract $(2.17 \pm 0.90)$. This finding was in coincidence with the observation of Kamboj et al., (2011) World Health Organization reportable that reduced aerophilous stress and increased inhibitor levels have additionally been discovered with wheatgrass treatment. throughout aging, mitochondria decay rates of oxidiser production increase and aerophilous injury to special biomolecules increase and should partly be to blame for aging similarly as age-associated chronic diseases. The cellular distribution and bioavailability of key inhibitors became altered with age. A shift within the oxidant: inhibitor balance due to increased production of free radicals is discovered throughout aging (Hagen, et al., 1997). الى هنا ونحتّاج الى تصديث المراجع

These results were in line with the results reportable by DeVogel et al. (2005) discovered that wheat-grass thought-about a

high nutritionary photoactive ingredients content that boost medicine price similarly as anti-inflammatory drug, antioxidant, immunomodulatory, anticarcinogenic, laxative, and anti-aging properties, and also the use of WG in hardening of the arteries, colitis, excretory organ malfunctions. Its high levels of enzymes and amino acids it work to rid of the body of stuff, and cut down the aging method (The web Journal of other medication, 2008).

In addition, Virág, et al. (2002) incontestable that the harmful result of overrun of free radicals on cells and tissues consequently ends up in diseases like carcinoma, skin condition and impaired 
skin wound healing. The seasoning medications to enhance $\mathrm{CBC}$ with higher outcome area unit a number of the alternatives and one in every of them is wheat grass that has shown promising ends up in that (Marawaha et al., 2004 and Singh et al,. 2010). Flavonoids are reportable to possess anti-inflammatory drug and medicament activities which could be to

blame for the sturdy inhibitor activity (Afolayan et al. 2008). Wheatgrass contains a minimum of thirteen vitamins (several of that area unit antioxidants) as well as B12, abscisic acid, SOD, hemoprotein enzyme, SOD converts 2 superoxide anions into a peroxide molecule, that has an additional gas molecule to kill cancer cells (Ernst, 2001).

\section{Effect of wheat-grass powder Extracts on Liver Functions in Aged Rats:}

Effect of Wheatgrass powder extracts on liver functions in aged rats was shown in Table (3). Total protein, albumin, globulin, AST and ALT activities were determined so as to indicate the effect of wheatgrass on aging factors. Aging caused a major increase in total protein, albumin and globulin levels in serum of control aged rats compared with control young rats as a results of oxidative stress related to aging which reduced liver functions. Administering aged rats with Wheat grass powder ethanolic and water extracts caused a significant decrease in total protein and albumin levels compared with control aged rats. the significant increase in total protein and albumin with aging is indication of compromised liver excretory function and impairment of the liver synthetic function, which improved by treating with Wheatgrass powder extracts. Ethanolic extract of Wheatgrass powder caused more practical improvement in total protein, albumin and globulin levels compared with water extract. From Table (3), it can be noticed that aging resulted in a very significant increase in liver enzymes aspartate 
aminotransferase (AST) and alanine aminotransferase (ALT) activities as a result of oxidative stress which reduced liver functions compared with control young rats. a big decrease in AST and ALT activities was found as a result of administering Wheatgrass powder ethanolic and water extracts orally to aged rats at the tip of the experimental period compared with control aged rats. AST and ALT enzymes is also released into plasma and serum levels of those enzymes may increase thanks to cellular damage within the liver. Liver enzymes activities were decreased to the traditional levels found in control young rats with non statistical significance after administration of Wheatgrass powder ethanolic and water extracts. From the current results, it can be found that serum total protein, albumin, globulin, AST and ALT levels were improved by administering Wheatgrass powder ethanolic extract followed by Wheatgrass powder water extract orally to aged rats which indicate an improvement in liver functions.

The increase of the activity of liver enzymes in serum is principally due to the leakage of those enzymes from the liver cytosol into the blood stream as mentioned by Mansour et al., (2002). additionally, Milagro et al., (2006) reported that, a link among increased fat depots, insulin resistance, and liver oxidative stress. These results were in line with the results reported by Arya and Kumar (2011) who demonstrated that triticum aestivum leaf extract affects liver enzyme activities also as lipid peroxidation. It showed a major hepatoprotective effect with a dose of $100 \mathrm{mg} / \mathrm{kg} /$ day in terms of SGOT, SGPT, ALP and Bilirubin in serum (Jain et al., 2007). Wheatgrass contains high levels of enzymes and amino acids work sort of a -natural cleanser\| to detoxify the liver, eliminate toxic heavy metals from the blood stream (The Internet Journal of alternative Medicine, 2008). 
This finding was in coincidence with the observation of Kamboj et al. (2011) who observed that the hepatoprotective effect of wheatgrass tablets in CCl4 treated rats has been investigated. Ann Wigmore (1985) explain this result by three compounds (Choline, magnesium and Potassium), found abundantly in wheatgrass, help the liver to remain vital and healthy. Choline works to stop the deposition of fat. Magnesium helps to extend excess fat within the same way. magnesium sulfate draws pus from an infection, and potassium acts as an invigorator and stimulant. Another flavenoid present in wheatgrass is Indole, which helps in synthesis of enzymes and deactivating carcinogens within the liver (Ann Wigmore, 1985).

Effect of Wheatgrass Extracts on Lipid Profiles and Triglycerides Levels in Aged Rats:

Effect of Wheatgrass powder extracts on cholesterol profiles and triglycerides levels in aged rats is mentioned in Table (4). Aging resulted during a significant increase in serum triglycerides levels compared with control young rats. Administering aged rats with Wheatgrass powder ethanolic and water extracts showed a significant reduction in triglycerides levels compared with control aged rats. Serum triglycerides levels seemed to be still elevated compared with control young rats although they're not statistically different. Aged rats received Wheatgrass powder ethanolic extract lowered their triglycerides levels from $154.30 \mathrm{mg} / \mathrm{dl}$ in control aged rats to $97.74 \mathrm{mg} / \mathrm{dl}$ (36.65\%), while Wheatgrass powder water extract caused $28.75 \%$ reduction in triglycerides levels at $20 \mathrm{mg}$ compared with control aged rats not receiving wheatgrass. It may be also observed from data in Table (4), total cholesterol, LDL cholesterol and VLDL-cholesterol levels significantly increased in aged rats compared with control young rats. 
The LDL-C/HDL-C ratio contributes to assess the danger of cardiovascular complications because of dyslipidemia (Sullivan, 2002). When aged rats were dosed with 10 and $20 \mathrm{mg}$ Wheatgrass powder ethanolic and water extracts, the amount of lipid profiles (total cholesterol, LDL and VLDL) were significantly reduced compared with control aged rats. The reduction was statistically significant for total cholesterol and LDL levels and insignificant for VLDL levels compared with control young rats. Ethanolic extract of Wheatgrass powder caused the very best reduction in lipid profiles followed by water extract. On the other, HDL-cholesterol level in aged rats significantly decreased compared with control young rats due to aging. Administering aged rats with Wheatgrass powder extracts caused a big increase within the levels of HDL-cholesterol compared with control aged rats and also the increase was significantly different by using Wheatgrass powder ethanolic extract compared with control young rats.

This finding was in coincidence with the observation of Saroj et al., (2008) who reported that treatment of rats with wheatgrass significantly lowered lipid parameters, TC, TG, LDL and VLDL-cholesterol were lowered. Further, it had been observed that HDL-cholesterol was increased in experimental groups as compared to control group.

Supplementation of high cholesterol diet in rats for 14 days resulted in significant $(\mathrm{p}<0.05)$ increase in TC and LDL-C levels as compared to the rats treated with normal diet. TC and LDL-C levels were increased by $202 \%$ and $333 \%$, respectively. the amount of TC, TG, LDL-C and VLDL-C were decreased by $50,22,56$ and 22 percent in rats treated with grass juice at the dose of $5 \mathrm{~mL} / \mathrm{kg}$ and by $60,38,69$ and 38 percent in rats treated with grass juice at the dose of $10 \mathrm{~mL} / \mathrm{kg}$, respectively. The decrease in TC, TG, LDL-C 
and VLDL-C levels were dose dependent and significant $(\mathrm{p}<0.05)$. HDLcholesterols shown a rise by 12 and 15 percent in 5 and $10 \mathrm{~mL} / \mathrm{kg}$, respectively, This effect was explained by Ben et al., (2002) who gave theories that the flavonoids, anti-inflammatory agents- apigenin and agropyrene contained in wheatgrass, played a task in alleviating symptoms Another flavonoid present in wheatgrass is Indole, which helps in synthesis of enzymes and deactivating carcinogens within the liver (Ann Wigmore 1985). Bioactive plant compounds flavonoids and triterpenoids are reported to modulate lipid levels (Koshi et al., 2001 and Zhang et al., 2008). The presence of flavonoids and triterpenoids in triticum aestivum grass might need contributed in lipid lowering effect of triticum aestivum grass juice in similar manner. Tannins are reported to extend in activity of the endothelium bound lipoprotein lipase activity which hydrolyzes triglycerides as reported by (Tebib et al., 1994).

According to Thiem and Grosslinka (2003) surface application of gear with free-radical scavenging properties has shown to significantly improve wound healing and protect tissues from oxidative damage. From the above mentioned results. it might be observed that aging caused a big deterioration altogether tested parameters and markers of aging including SOD enzyme activity, liver functions (total protein, albumin, globulin, AST and ALT levels), lipid profiles (total cholesterol, HDL, LDL, VLDL and triglycerides). a major reduction was observed in SOD, total protein, albumin, globulin, HDL-cholesterol, hemoglobin, while a big increase was found in AST and ALT activities, triglycerides levels, total cholesterol, LDL and VLDL levels as a result of oxidative stress related to aging. Administering aged rats with Wheatgrass ethanolic and water extracts at dose of $20 \mathrm{mg} /$ daily caused a big improvement within the above mentioned markers and Wheatgrass extracts 
were found to manage the rise or the decrease within the disorder parameters which changed during aging compared with young rats. Wheatgrass extracts returned the abnormal markers back to the traditional levels found in control young rats or nearest to them with the very best improvement achieved by using ethanolic extract. So, it might be recommended that Wheatgrass extracts might be used as natural materials to boost the abnormal changes in health state of aging populations and return them to just about the traditional state found in younger populations owing to their antioxidant activity.

Table 1: Effect of Wheatgrass extracts on body weight aged rats.

\begin{tabular}{|c|c|c|}
\hline Groups & $\begin{array}{c}\text { Initial body } \\
\text { weight }(\mathbf{g})\end{array}$ & $\begin{array}{c}\text { Final body weight } \\
(\mathbf{g})\end{array}$ \\
\hline Con (-) & $\begin{array}{c}108.12 \mathrm{a} \pm \\
2.13\end{array}$ & $115.32 \mathrm{a} \pm 1.45$ \\
\hline Con (+) & $\begin{array}{c}269.87 \mathrm{~b} \pm \\
3.15\end{array}$ & $253.45 \mathrm{~b} \pm 2.25$ \\
\hline $\begin{array}{c}\text { Water extract } \\
\text { 10 mg }\end{array}$ & $\begin{array}{c}267.33 \mathrm{~b} \pm \\
1.56\end{array}$ & $233.25 \mathrm{c} \pm 1.85$ \\
\hline $\begin{array}{c}\text { Water extract } \\
\text { 20 mg }\end{array}$ & $\begin{array}{c}265.89 \mathrm{~b} \pm \\
2.45\end{array}$ & $225.17 \mathrm{~d} \pm 3.21$ \\
\hline $\begin{array}{c}\text { Alcohol } \\
\text { extract 10 mg }\end{array}$ & $\begin{array}{c}264.65 \mathrm{~b} \pm \\
1.98\end{array}$ & $228.14 \mathrm{c} \pm 2.82$ \\
\hline $\begin{array}{c}\text { Alcohol } \\
\text { extract 20 mg }\end{array}$ & $\begin{array}{c}268.23 \mathrm{~b} \pm \\
2.69\end{array}$ & $213.47 \mathrm{~d} \pm 1.94$ \\
\hline F & 253.44 & 342.23 \\
\hline Sig. & 0.00 & 0.00 \\
\hline
\end{tabular}

*Numbers in the same column having different letters are significantly differed at $\mathrm{p}<0.05$.

Table 2: Effect of Wheatgrass extracts on antioxidant enzymes and lipid peroxidation in aged rats. 


\begin{tabular}{|c|c|c|}
\hline Groups & $\begin{array}{c}\text { SOD (n. } \\
\text { mol/mg/ } \\
\text { protein) }\end{array}$ & $\begin{array}{c}\text { MDA (n. mol/mg/ } \\
\text { protein) }\end{array}$ \\
\hline Mean \pm SD & Mean \pm SD \\
\hline Con (-) & $52.54 \mathrm{~d} \pm 3.65$ & $0.52 \mathrm{~d} \pm 0.04$ \\
\hline Con (+) & $10.69 \mathrm{a} \pm 1.03$ & $14.55 \mathrm{a} \pm 1.15$ \\
\hline $\begin{array}{c}\text { Water extract } \\
\text { 10 mg }\end{array}$ & $27.47 \mathrm{~b} \pm 1.94$ & $9.83 \mathrm{~b} \pm 0.58$ \\
\hline $\begin{array}{c}\text { Water extract } \\
\mathbf{2 0} \text { mg }\end{array}$ & $34.46 \mathrm{c} \pm 1.91$ & $6.33 \mathrm{c} \pm 1.27$ \\
\hline $\begin{array}{c}\text { Alcohol } \\
\text { extract 10 mg }\end{array}$ & $31.92 \mathrm{c} \pm 1.41$ & $7.84 \mathrm{~b} \pm 0.46$ \\
\hline $\begin{array}{c}\text { Alcohol } \\
\text { extract 20 mg }\end{array}$ & $40.30 \mathrm{~b} \pm 1.00$ & $2.17 \mathrm{c} \pm 0.90$ \\
\hline F & 353.47 & 433.58 \\
\hline Sig. & 0.00 & 0.00 \\
\hline
\end{tabular}

*Numbers in the same column having different letters are significantly differed at $\mathrm{p}<0.05$.

Table 3: Effect of Wheatgrass extracts on liver functions in aged rats.

\begin{tabular}{|c|c|c|c|c|c|}
\hline Groups & $\begin{array}{l}\text { Total } \\
\text { protein } \\
(\mathbf{U} / \mathbf{L})\end{array}$ & $\begin{array}{l}\text { Albumin } \\
\text { (U/L) }\end{array}$ & $\begin{array}{c}\text { Globulin } \\
\text { (U/L) }\end{array}$ & $\begin{array}{c}\text { AST } \\
(\mathbf{U} / \mathbf{L})\end{array}$ & $\begin{array}{l}\mathbf{A L T} \\
(\mathbf{U} / \mathbf{L})\end{array}$ \\
\hline & $\begin{array}{c}\text { Mean } \pm \\
\text { SD }\end{array}$ & $\begin{array}{l}\text { Mean } \pm \\
\text { SD }\end{array}$ & $\begin{array}{c}\text { Mean } \pm \\
\text { SD }\end{array}$ & $\begin{array}{l}\text { Mean } \pm \\
\text { SD }\end{array}$ & $\begin{array}{c}\text { Mean } \pm \\
\text { SD }\end{array}$ \\
\hline Con (-) & $\begin{array}{c}15.01 \mathrm{~d} \pm \\
2.70\end{array}$ & $\begin{array}{c}6.05 \mathrm{c} \pm \\
3.56\end{array}$ & $\begin{array}{c}12.33 \mathrm{~d} \pm \\
0.56\end{array}$ & $\begin{array}{c}36.10 \mathrm{~d} \\
\pm 0.90\end{array}$ & $\begin{array}{c}26.15 \mathrm{~d} \pm \\
0.89\end{array}$ \\
\hline Con $(+)$ & $\begin{array}{c}131.14 \mathrm{a} \\
\pm 1.70\end{array}$ & $\begin{array}{c}34.18 \mathrm{a} \pm \\
1.89\end{array}$ & $\begin{array}{c}102.99 \mathrm{a} \\
\pm 9.90\end{array}$ & $\begin{array}{c}115.48 \mathrm{a} \\
\pm 3.70\end{array}$ & $\begin{array}{c}99.05 \mathrm{a} \pm \\
0.85\end{array}$ \\
\hline $\begin{array}{c}\text { Water } \\
\text { extract } 10 \\
\text { mg }\end{array}$ & $\begin{array}{c}112.57 \mathrm{~b} \\
\pm 2.00\end{array}$ & $\begin{array}{l}28.14 \mathrm{~b} \\
\pm 11.51\end{array}$ & $\begin{array}{c}84.43 \mathrm{~b} \pm \\
1.48\end{array}$ & $\begin{array}{c}101.40 \mathrm{~b} \\
\pm 7.25\end{array}$ & $\begin{array}{c}84.40 \mathrm{~b} \pm \\
2.98\end{array}$ \\
\hline $\begin{array}{c}\text { Water } \\
\text { extract } 20 \\
\text { mg }\end{array}$ & $\begin{array}{c}99.11 \mathrm{c} \pm \\
0.52\end{array}$ & $\begin{array}{l}27.25 \mathrm{~b} \\
\pm 12.53 \\
\end{array}$ & $\begin{array}{c}72.93 \mathrm{c} \pm \\
1.61\end{array}$ & $\begin{array}{l}81.74 \mathrm{c} \\
\pm 2.31\end{array}$ & $\begin{array}{c}70.76 \mathrm{c} \pm \\
1.43\end{array}$ \\
\hline $\begin{array}{l}\text { Alcohol } \\
\text { extract } 10 \\
\text { mg }\end{array}$ & $\begin{array}{c}107.03 \mathrm{~b} \\
\pm 1.50\end{array}$ & $\begin{array}{c}28.23 \mathrm{~b} \pm \\
5.43\end{array}$ & $\begin{array}{c}79.85 \mathrm{~b} \pm \\
3.66\end{array}$ & $\begin{array}{c}54.02 \mathrm{c} \\
\pm 3.00\end{array}$ & $\begin{array}{c}44.08 \mathrm{c} \pm \\
3.60\end{array}$ \\
\hline
\end{tabular}




\begin{tabular}{|c|c|c|c|c|c|}
\hline $\begin{array}{c}\text { Alcohol } \\
\text { extract 20 } \\
\text { mg }\end{array}$ & $\begin{array}{c}55.35 \mathrm{c} \pm \\
3.66\end{array}$ & $\begin{array}{c}4.32 \mathrm{c} \pm \\
3.07\end{array}$ & $\begin{array}{c}50.40 \mathrm{c} \pm \\
2.23\end{array}$ & $\begin{array}{c}44.66 \mathrm{~d} \\
\pm 2.76\end{array}$ & $\begin{array}{c}40.55 \mathrm{~d} \pm \\
2.73\end{array}$ \\
\hline F & 3982.55 & 35.130 & 273.13 & 397.04 & 1909.07 \\
\hline Sig. & 0.00 & 0.000 & 0.00 & 0.00 & 0.00 \\
\hline
\end{tabular}

*Numbers in the same column having different letters are significantly differed at $\mathrm{p}<0.05$.

AST $=$ Aspartate aminotransferase $\quad$ ALT $=$ alanine aminotransferase

Table (4): Effect of Wheatgrass extracts on lipid profiles and triglycerides levels in aged rats (mg/dl).

\begin{tabular}{|c|c|c|c|c|c|}
\hline Groups & $\begin{array}{c}\text { Cholesterol } \\
\text { (mg/dl) }\end{array}$ & $\begin{array}{c}\text { Triglycride } \\
\text { (mg/dl) }\end{array}$ & $\begin{array}{c}\text { HDL } \\
(\mathbf{m g} / \mathbf{d l})\end{array}$ & $\begin{array}{c}\text { LDL } \\
(\mathrm{mg} / \mathrm{dl})\end{array}$ & $\begin{array}{l}\text { VLDL } \\
\text { (mg/dl) }\end{array}$ \\
\hline & Mean \pm SD & Mean \pm SD & $\begin{array}{c}\text { Mean } \pm \\
\text { SD }\end{array}$ & $\begin{array}{c}\text { Mean } \pm \\
\text { SD }\end{array}$ & $\begin{array}{l}\text { Mean } \pm \\
\text { SD }\end{array}$ \\
\hline Con (-) & $\begin{array}{c}59.53 \mathrm{~d} \pm \\
1.39\end{array}$ & $\begin{array}{c}87.48 \mathrm{~d} \pm \\
1.57\end{array}$ & $\begin{array}{c}32.62 \mathrm{a} \\
\pm 0.39\end{array}$ & $\begin{array}{c}16.37 \mathrm{~d} \\
\pm 2.13 \\
\end{array}$ & $\begin{array}{c}17.50 \mathrm{~d} \\
\pm 0.31\end{array}$ \\
\hline Con $(+)$ & $\begin{array}{c}110.98 \mathrm{a} \pm \\
9.31\end{array}$ & $\begin{array}{c}154.30 \mathrm{a} \pm \\
2.31\end{array}$ & $\begin{array}{c}12.22 \mathrm{~d} \\
\pm 0.98 \\
\end{array}$ & $\begin{array}{c}110.07 \\
a \pm 0.93\end{array}$ & $\begin{array}{c}30.86 \mathrm{a} \pm \\
0.46\end{array}$ \\
\hline $\begin{array}{l}\text { Water } \\
\text { extract } \\
10 \mathrm{mg}\end{array}$ & $\begin{array}{c}98.57 \mathrm{~b} \pm \\
2.10\end{array}$ & $\begin{array}{c}142.61 \mathrm{~b} \pm \\
1.22\end{array}$ & $\begin{array}{c}19.00 \mathrm{c} \\
\pm 1.03\end{array}$ & $\begin{array}{c}90.42 \mathrm{~b} \\
\pm 1.59\end{array}$ & $\begin{array}{c}23.89 \mathrm{~b} \\
\pm 0.64\end{array}$ \\
\hline $\begin{array}{c}\text { Water } \\
\text { extract } \\
20 \mathrm{mg}\end{array}$ & $\begin{array}{c}79.16 \mathrm{~b} \pm \\
1.29\end{array}$ & $\begin{array}{c}109.93 \mathrm{~b} \pm \\
2.24\end{array}$ & $\begin{array}{c}25.80 \mathrm{c} \\
\pm 0.64\end{array}$ & $\begin{array}{c}67.07 \mathrm{~b} \\
\pm 1.98\end{array}$ & $\begin{array}{c}21.99 \mathrm{~b} \\
\pm 0.45\end{array}$ \\
\hline $\begin{array}{l}\text { Alcohol } \\
\text { extract } \\
10 \mathrm{mg}\end{array}$ & $\begin{array}{c}87.67 \mathrm{c} \pm \\
4.22\end{array}$ & $\begin{array}{c}134.27 \mathrm{c} \pm \\
2.14\end{array}$ & $\begin{array}{l}21.80 \mathrm{~b} \\
\pm 1.94\end{array}$ & $\begin{array}{l}78.82 \mathrm{c} \\
\pm 6.62\end{array}$ & $\begin{array}{c}22.23 \mathrm{~b} \\
\pm 0.55\end{array}$ \\
\hline $\begin{array}{l}\text { Alcohol } \\
\text { extract } \\
20 \mathrm{mg} \\
\end{array}$ & $\begin{array}{c}70.62 \mathrm{c} \pm \\
1.23\end{array}$ & $\begin{array}{c}97.74 \mathrm{c} \pm \\
2.39\end{array}$ & $\begin{array}{c}28.23 \mathrm{~b} \\
\pm 0.86\end{array}$ & $\begin{array}{c}54.44 \mathrm{c} \\
\pm 2.49\end{array}$ & $\begin{array}{c}19.55 \mathrm{c} \pm \\
0.48\end{array}$ \\
\hline $\mathbf{F}$ & 104.30 & 1486.13 & 291.50 & 760.54 & 1122.191 \\
\hline Sig. & 0.00 & 0.00 & 0.00 & 0.00 & 0.000 \\
\hline
\end{tabular}

* Numbers in the same column having different letters are significantly differed at $\mathrm{p}<0.05$. 


\section{RERERENCES}

A.O.A.C. (2006): Official Methods of Analysis. 18th Edition, Association of Official Agricultural Chemists. Washington D.C., USA.

Afolayan A.J., Aboyade O.M. and Sofidiya M.O. (2008): Total Phenolic Content and Free Radical Scavenging Activity of Malva parviflora L. (Malvaceae), Journal of Biological Sciences (8) 5: 945 - 949.

Ann Wigmore (1985): The Wheatgrass book, Avery publishing group Inc. Wayne, New Jersey.

Arya P. and Kumar M. (2011): Chemoprevention by Triticum Aestivum of Mouse Skin Carcinogenesis Induced by DMBA and Croton Oil Association with Oxidative Status. Asian Pacific J Cancer Prev, 12:143-148.

Assmann, G. (1979): Cholesterol determination in high density lipoproteins separated by three different methods. Internist, 20: 559-604.

Barja (2004): "Free radicals and aging," Trends in Neurosciences, vol. 27, no. 10, pp. 595-600,.View at: Publisher Site | Google Scholar

Begona, R. L.; Leal, A.M.; Liza, M.; Lacort, M. and Degroot, H. (1994): Antioxidant effects of esteradiol and 2- hydroxy estradiol on ironinduced lipid peroxidation of rat liver microsomes. Steroids, 59:388389.

Bergmeyer, H.U. And Harder M. (1986): A colorimetric method of the determination of serum glutamic oxaloacetic and glutamic pyruvic transaminase. Clin. Biochem., 24: 458-481.

Borcea, V.J., Nourooz-Zadeh S.P.; Wolff M., Slevesath H., Urich M. and Nawroth P.P. (1999): Alpha-lipoic acid decreases oxidative stress even in diabetic patients with poor glycemic control and albuminuria. Free Radic. Biol. Med., 26: 1495-1500. 
Desai, S; Tusharbindu, R. (2005): Investigation into the mechanism of action and effects of triticum aestivum (Wheat) grass, Ph.D., Thesis, Saurashtra University.

DeVogel J, Denize SML, Jonker TM, Katan MB, van der Meer R (2005): Natural chlorophyll but not chlorophyllin prevents heme-induced cytotoxic and hyperproliferative effect in rat colon. J Nutr 135:19951900.

Ernst E. (2006): A primer of complementary and alternative medicine commonly used by cancer patients. Medical J aust, 174:88-92. Clin Exp Rheumatol. May-Jun;24(3):325-8.

Farhan H., Rammal H., Hijazi A. and Badran B. (2012): Preliminary phytochemical screening and extraction of polyphenol from stems and leaves of a Lebanese plant M. parviflora L., Int. J, Curr Pharm Res, 4(1), 55-59.

Ferruzzia MG, Blakesleeb J (2007): Digestion, absorption and cancer preventive activity of dietary chlorophyll derivatives. Nutr Res 27:112.

Flynn M.G., Markofski M. M and Carrillo A. E. (201 Schnabel 9): Elevated inflammatory status and increased risk of chronic disease in chronological aging: inflamm-aging or inflamm-inactivity? Aging Dis; 10: 147-156, doi: 10.14336/AD.2018.0326.

Ghoniem AA; Abou- Raya1MA; Abd EL Hameed AK and Elrayes N M. (2018): Influence of Using Fresh Wheat Grass Juice and its Blends on Hypercholesterolemic Rats J. Food and Dairy Sci., 3rd Mansoura International Food Congress (MIFC) October: 137 - 145. 
Habig, W.B., M.J. Pabst and W.P. Jakoby (1974): Glutathione-stransferases. The first enzymatic step in mercapturic acid formation. J. Biol. Chem., 249: 7130-7139.

Hagen, T.M., D.L. Yowe, J.C. Bartholomew, C.M. Wehr, J.Y. Park and B.N. Ames (1997): Mitochondrial decay in hepatocytes from old rats: membrane potential declines, heterogenicity and oxidants increase. Proc.Natl. Acad. Sci., USA 94: 3064-3069.

Hatch, F.T. and R.S. Lees (1968): Practical methods for plasma lipoprotein analysis. Adv. Lipid Res., 6:1-6.

Jain G, Argal A., Pathak A.K, Singh and V.K, Kannojia P (2007): Hepatoprotective activity of wheatgrass juice. The pharmacist 2007, 2(1) 29-30.

Kamboj J. K., Rana S. V., Ola R. P., Dhawan D K and Vahiphei K. (2011): Wheatgrass and antioxidant levels in carbon tetrachloride induced hepatotoxicity in rats, J. Clinical and Experimental Hepatology, 1:S1.

Koshi A.S., Anita L. and Vijayalakshmi N. R. (2001): Food Chem. 72, 289.

Lalone, C.A., K.D. Hammer, L. Wu, N. Leyva, A.K. Solco, G.A. Kraus, K. Kim, K. Seo and D.F. Birt (2007): Echinacea species and alkamides inhibit prostaglandin E2 production in RAW264.7 mouse macrophage cells. J. Agric. Food Chem., 55(18): 7314-7322.

Lee, R. and Nieman, D. (1996): Nutritional Assessment; 2nd ed Mosby Missouri, USA.

Lowry, O.H., N.J. Rosebrough, A.L. Farr and R.J. Randall (1951): Protein measurement with the Folin phenol reagent. J. Biol. Chem., 193: 265-275. 
Mansour, H.A., A.S. Newairy, M.I. Yousef and S.A. Sheweita (2002): Biochemical study on the effects of some Egyptian herbs in alloxaninduced diabetic rats. Toxicology, 170: 221-228.

Marawaha RK, Bansal D, Kaur S, Trehan A. (2004): Wheat grass juice reduces transfusion requirement in patients with thalasemia major: a pilot study. Indian Pediatr;41(7):716-20.

Marklund, S. and C. Marklund (1974): Involvement of the superoxide anion radical in the autoxidation of pyrogallol and a convenient assay for superoxide dismutase. Eur. J. Biochem., 47: 469-474.

Milagro F.I, Campio'n J. and Martı'nez A. (2006): Weight gain induced by high-fat feeding involves increased liver oxidative stress. OBESITY, 14 (7): 1118-1123.

Montelius C., Erlandsson D., Vitija E., Stenblom E., Egecioglu E. and Erlanson-Albertsson C. (2014): Body weight loss, reduced urge for palatable food and increased Release of GLP-1 through daily supplementation with green-plant membranes for three months in overweight women 295-304.

Roeschlau, P., E. Bernt and W.J. Gruber (1974): Kinetics of the cholesterol-sulfuric acid reaction. A fast kinetic method for serum cholesterol. Clin. Chem. Clin. Biochem., 12: 403-408.

Saroj Kothari, Anand K. Jain, Swaroop C. Mehta, and Shrinivas D. Tonpay (2008): Effect of fresh Triticum aestivum grass juice on lipid profile of normal rats. Indian J Pharmacol. Oct; 40(5): 235236.doi: 10.4103/0253-7613.44157.

SAS (1996): Statistical Analysis System, ASA User's Guide: Statistics. SAS Institute Inc. Editors, Cary, NC. 
Schnabel RB, Yin X, Larson MG, Yamamoto JF, Fontes JD, Kathiresan S, et al. (2013): Multiple inflammatory biomarkers in relation to cardiovascular events and mortality in the community. Arterioscler Thromb Vasc Biol; 33: 1728-1733, doi: 10.1161/ATVBAHA.112.301174.

Singh K, Pannu MS, Singh P, Singh J. (2010): Effect of wheat grass tablets on the frequency of blood transfusion in Thalassemia Major. Indian $\mathbf{J}$ Pediatr;77(1):90-91

Sullivan D.R. (2002): Screening for cardiovascular disease with cholesterol. Clin. Chim. Acta., 315, 49-60.

Tebib K., Besancon P. and Rounanet J.M. (1994): J. Nutr. 124, 2451.

The Internet Journal of Alternative Medicine (2008): Wheat J, Currie J: Herbal medicine for cancer patients: An evidence based review., 5: 28-30

Uwajima, T., Y. Shimizu and O. Ferda (1984): Glycerol oxidase, a novel copper hemoprotein from Aspergillus japonicus. J. Biol. Chem., 259: 2748-2753.

Virág, T.M., D.L. Yowe, J.C. Bartholomew, C.M. Wehr, J.Y. Park and B.N. Ames (1997): Mitochondrial decay in hepatocytes from old rats: membrane potential declines, heterogenicity and oxidants increase. Proc. Natl. Acad. Sci., USA 94: 3064-3069.

Vogel, A.I., Tatchell, A.R., Furnis, B.S., Hamaford, A.J. and Smith, P.W.G. (1978): Vogel's text book of practical organic chemistry: (5th Ed.). The English book society and Longman, U.K. pp. 137.

Von Bohlen Und Halbach, C. Zacher, P. Gass, and K. Unsicker (2006):“Age-related alterations in hippocampal spines and 
deficiencies in spatial memory in mice," Journal of Neuroscience Research, vol. 83, no. 4, pp. 525-531.

Wheat J, Currie J (2008): Herbal medicine for cancer patients: an evidence based review. Internet J Altern Med 5:28-30.

Xia S, Zhang X, Zheng S, Khanabdali R, Kalionis B, Wu J, et al. (2016): An update on inflamm-aging: mechanisms, prevention, and treatment. J Immunol Res; 8426874, doi: 10.1155/8426874.

Zhang Q., Chang Z., Yang J. and Wang Q. (2008): Phytother. Res. 22, 1040. 